Review of Income and Wealth

Series 54, Number 2, June 2008

\title{
POVERTY DYNAMICS DURING TRADE REFORM: EVIDENCE FROM RURAL VIETNAM
}

\author{
BY PAtricia Justino \\ Institute of Development Studies, University of Sussex \\ Julie Litchfield* and Hung Thai Pham \\ Poverty Research Unit at Sussex and Department of Economics, University of Sussex
}

\begin{abstract}
This paper implements and adapts the conceptual framework developed by Winters (2002) that identifies the transmission mechanisms between trade policy reform and household welfare outcomes. We make use of household panel data from Vietnam collected in two years, 1992-93 and 1997-98 that span the very earliest years of the reform period and its immediate after effects. Poverty dynamics are modeled using changes in consumption expenditure and poverty transition models. The trade effect is captured by a set of variables that are most likely to have an impact on rural poverty, namely prices of staples and employment in the export sector. We show that trade liberalization has a material and positive effect on rural household welfare and this trade effect is largely transmitted to the poor through the labor market channel.
\end{abstract}

\section{INTRODUCTION}

The dynamics of poverty has long been an issue of greatest concern in economics and social policy (Bane and Ellwood, 1986; Lipton and Ravallion, 1995). The differentiation between persistent and transient poverty, as well as the characterization of the socio-economic characteristics of individuals and households that move in and out of poverty, are key to the design of effective poverty-alleviating policies. They are also of considerable interest in the current debate surrounding the effects of trade liberalization in developing countries. While greater openness to trade is generally believed to provide opportunities for many people, especially those in less developed economies, it is likely that some may not benefit from these opportunities, and may even suffer from trade reforms and the resulting vulnerability to trade shocks (see McCulloch et al., 2001 for a review). A key question is to identify the characteristics and constraints that contribute towards the persistence of poverty and the extent to which trade reform impacts on poverty dynamics.

We examine this question in the context of Vietnam although we believe the approach we follow can be applied to a number of other developing countries

Note: We are grateful to Bob Baulch, Rhys Jenkins, Neil McCulloch, Andy McKay, Howard White and, in particular, Alan Winters, for useful discussions and to Yoko Niimi and Puja Vasudeva-Dutta for excellent research assistance. We would also like to thank the participants of seminars and conferences at Sussex, Nottingham, Hanoi, IARIW, DIW Berlin and Warsaw for helpful comments on earlier drafts of the paper, and in particular two anonymous referees of an earlier draft. This paper is part of the project "The Impact of Trade Reforms and Trade Shocks on Household Poverty Dynamics" (ESCOR-R7621) funded by the UK Department for International Development as part of their Globalisation and Poverty Research Programme. Views and opinions expressed in this paper are those of the authors alone.

*Correspondence to: Julie Litchfield, Dept of Economics, University of Sussex, Falmer, Brighton BN1 9SN, UK (j.a.litchfield@sussex.ac.uk).

(C) 2008 The Authors

Journal compilation (C) 2008 International Association for Research in Income and Wealth Published by Blackwell Publishing, 9600 Garsington Road, Oxford OX4 2DQ, UK and 350 Main St, Malden, MA, 02148, USA. 
experiencing trade reforms. Vietnam has been regarded as one of the success stories in the attack on poverty in developing countries. The economic and social changes experienced by Vietnam have been largely ascribed to the "doi moi," or renovation policies, designed in 1986 and implemented during the early part of the 1990s. ${ }^{1}$ The largest and most visible economic changes took place in the export sector, particularly in the rice market, where many tariffs were reduced or eliminated, price controls on important inputs such as fertilizers were removed, and extended land use rights were granted to farmers. ${ }^{2}$ During the 1990 s, Vietnam experienced very strong GDP per capita growth accompanied by increases in real consumption and a significant decline in poverty (see Table 1). The reduction in poverty was however more pronounced for some groups than others: urban households, households in the south of the country, the majority ethnic group (Kinh), and white-collar workers experienced much sharper falls in poverty than other groups; furthermore, a significant number of households remained poor over the large part of the 1990s (Glewwe et al., 2002; Litchfield and Justino, 2004).

However, the link between trade reforms and transitional (or permanent) poverty is not easy to establish empirically. Households themselves are complex units, being composed of multiple members receiving incomes from multiple sources. They are also dynamic units, and any trade-induced household changes (such as changes in production and marketing methods) may coincide with other household events, such as births and deaths, as well as with other income shocks not necessarily due to trade policy reform. Hence a household's move out of or into poverty can not necessarily be ascribed to a change in trade policy. In addition, trade reforms tend to be highly complex, often involving simultaneous changes in a large number of tariff and non-tariff barriers that affect both consumers and producers in different markets. These two aspects make it extremely difficult to link trade reforms in general to household movements in and out of poverty.

One approach to this problem is to define some measure of "openness" and attempt to link changes in poverty to changes in this measure. This approach has been used extensively in the cross-country literature on the linkages between openness and growth (Sachs and Warner, 1995; Edwards, 1998; see Rodriguez and Rodrik, 1999 for a review). However, this approach ignores important, and potentially variable, welfare effects at the microeconomic level. In order to assess the impact of trade reforms at the household level, we need to identify specific household events that can be linked to trade reforms.

The objective of this paper is to propose practical ways of identifying the impact of trade reform at the household level using household survey data. As our starting point we use Winters (2002) who proposes three transition mechanisms or channels from trade reforms to household welfare outcomes: a price channel, an

${ }^{1}$ Placing an exact start date for doi moi is difficult. Plans for reform were discussed as early as the late 1970 s, but there is widespread agreement in the literature that the reforms did not get underway until the early 1990s and particularly only after Vietnam joined ASEAN in 1995 (see World Bank, 2000; Benjamin and Brandt, 2002; Haughton et al., 2001). In addition, an inspection of the data on exports and imports, some of which is shown in Table 1, suggests that the effects of the trade reforms were not felt until after 1992-93. reforms.

${ }^{2}$ See Athukorala (2002) and Auffret (2003), inter alia, for a discussion of Vietnam's trade policy 


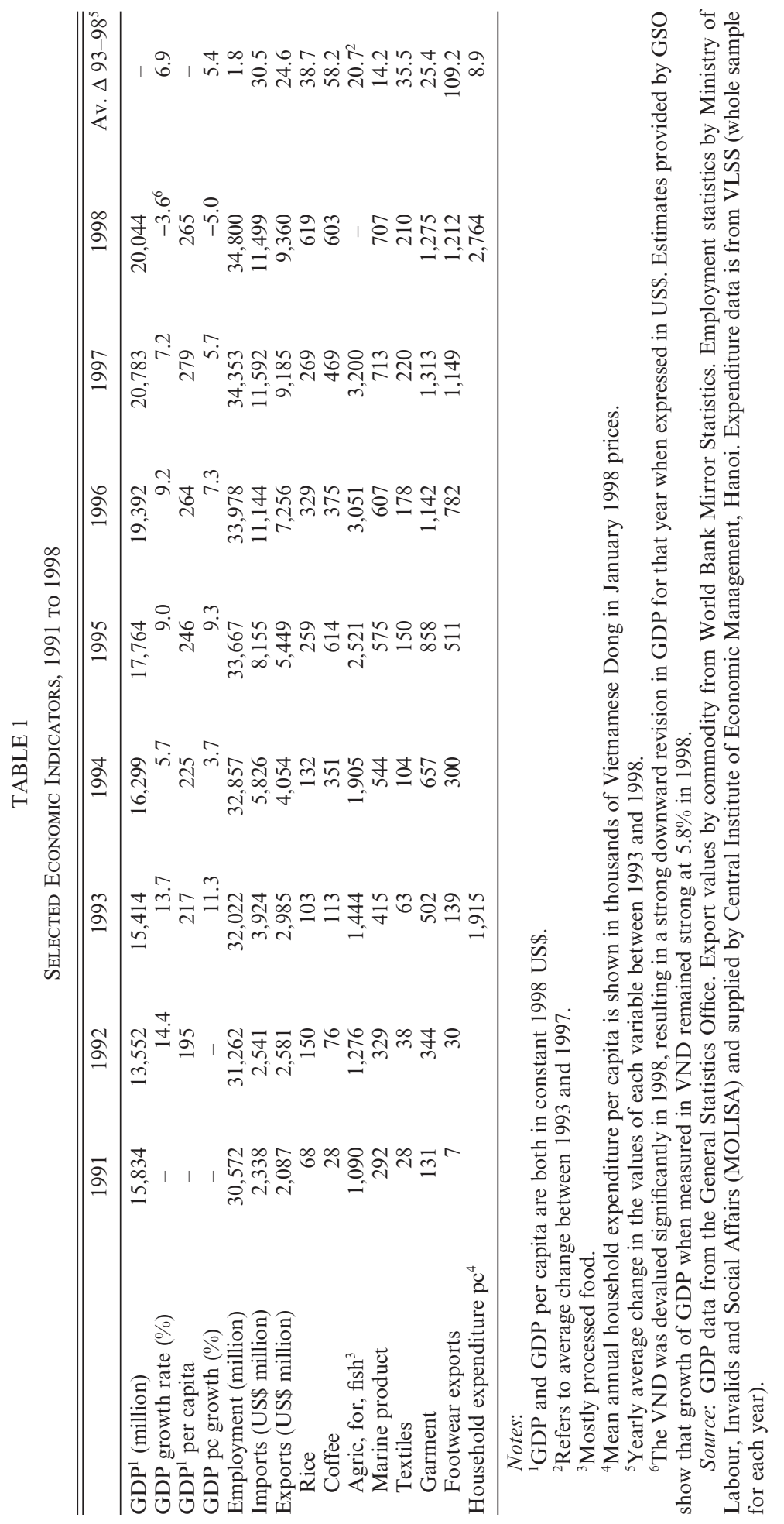


employment channel and a fiscal channel. ${ }^{3}$ Specifically, we focus on aspects of those channels most likely to have had an impact on rural households. The first of these in the Vietnamese context is related to the key food staple, rice. ${ }^{4}$ In the early 1990 s rice export quotas were increased significantly and the private sector was allowed a greater role in the production and export of rice. Rice production and exports increased sharply from the early 1990s (see Table 1), turning the country from a net rice importer at the start of the decade to the second largest exporter of rice in 1997 after Thailand (in quantity terms). ${ }^{5}$ As a result, rice producers benefited from rising international rice prices, increased production volumes and a rise in productivity. ${ }^{6}$ Our analysis uses changes in rice prices and rice productivity to capture the price channel. The second channel concerns employment and rural labor markets. During the 1990s there was very little employment growth (see Table 1), and industry's share of employment remained very stable despite a rising share of GDP. However, Niimi et al. (2002) argue that employment growth in the top ten export commodity sectors (including seafood, food processing, textiles and shoes) is a direct result of trade reform. They estimate that these export commodities generated 4.5 percent more jobs for the economy between 1993 and 1998. Jenkins (2003) enhances this finding and reveals a number of around 100,000 new jobs per annum created as the net employment effect of trade liberalization. Our analysis uses changes in the share of workers employed in key export sectors to capture the employment channel. This approach allows us to provide a direct link between trade reforms and poverty, and provides a contrast with the more common approach of analyzing the impact of trade reforms on particular types of household members (e.g. workers in manufacturing) or on particular sources of income (e.g. wages). ${ }^{7}$

The above is not straightforward. Beyond the conceptual problems of identifying trade reforms and their channels, there are two significant analytical issues which we aim to address, one relating to the choice between discrete "poverty" and continuous "income" models and another relating to endogeneity between poverty changes and other household events.

First, discrete poverty models are usually subject to the criticism that results are based on arbitrarily defined poverty lines imposed on the total distribution of household consumption or income, the "real" behavioral variables. ${ }^{8}$ In defense of

\footnotetext{
${ }^{3}$ Winters argues that changes in tax revenue as a result of changes in trade policy may affect household welfare through changes in government spending and in particular through changes in anti-poverty programs. Unfortunately the data available at either household or the local commune level in Vietnam is very sparse, so we are unable to explore this with our data.

${ }^{4}$ Earlier versions of this paper incorporated coffee (the main cash crop) in the analysis. However, because of the geographic concentration of coffee production in a relatively small area of the country and among a relatively small proportion of rural households, and in order to simplify the analysis and discussion, we focus here on rice.

${ }^{5}$ Vietnam's exports of rice in volume terms made up 17 percent of total world rice exports in 1997. However, this corresponded to 5 percent in value terms (which puts Vietnam as the sixth largest exporter of rice in value terms in 1997). The lower value share has been attributed to the inferior quality of Vietnamese rice (Nielsen, 2002).

${ }^{6}$ The increase in rice productivity is due in part to a fall in the area of land cultivated with rice as well as decreases in the price of fertilizers following the removal of price controls on fertilizers in the mid 1990s (Benjamin and Brandt, 2002; Nielsen, 2002).

${ }^{7}$ See Goldberg and Pavcnik (2004) for a review.

${ }^{8}$ See Deaton (1997) for discussion. Moreover, underlying variables may themselves be subject to measurement errors (see Deaton, 2003; Ravallion, 2003).
} 
the poverty-outcome approach, Appleton (2002) showed that, in the context of static poverty analysis, focusing attention on poverty outcomes rather than the continuous distribution of the relevant welfare indicator, may be preferable if the determinants of welfare have different returns to the poor and the non-poor. In this paper, we adopt both discrete and continuous approaches, with the addition of applying the latter to examine the determinants of welfare changes at different quintiles of the initial expenditure distribution.

Second is the thorny issue of endogeneity. Variables that capture trade reform induced events at the household level, i.e. those that reflect the transmission mechanisms such as changes in employment, prices and productivity of key staples, may be endogenous to changes in welfare, and so to changes in poverty state. Changes in the price received by a household for its rice, for example, may just as easily reflect changes in the household's living standards, output and market position as any changes in trade policy. Many studies of poverty dynamics, or related welfare indicators, therefore focus solely on assessing the role of initial conditions, thereby avoiding any endogeneity problems, but in so doing they ignore potentially important changes in the conditions that drive poverty dynamics. Our paper tackles the issue head-on by explicitly acknowledging that endogeneity is likely to be a problem; we explore two practical solutions. We do so in two different ways, each of which provides useful practical lessons for household survey analysis. We first adopt a two-stage least squared (2SLS) approach using several sets of instruments for these potentially endogenous variables, including variables at both household and community level, that arguably affect changes in employment and rice prices and productivity but not changes in expenditure or poverty state. We apply an array of tests to determine if these instruments are useful in addressing the endogeneity problem. Our results from this first approach highlight the difficulty in finding adequate instruments and the caution needed when applying standard exogeneity tests. ${ }^{9}$ As an alternative approach we use commune level variables to capture trade events rather than household level variables. For example, the change in the unit-value received by a household for its rice output is replaced by the average price in the commune as reported in the commune questionnaire. Measuring changes at the commune level has the advantage of not only being much less prone to endogeneity issues but also of representing the economic environment (price, employment and fiscal) which the household faces rather than decisions and responses of the household. ${ }^{10}$

One important feature of this paper is its focus on the rural sector. Existing analyses of trade reforms tend to concentrate on changes in wages and employment of different categories of workers in the formal manufacturing sector (usually in urban areas), namely skilled versus unskilled workers. Although changes in employment patterns in the urban sector may affect some rural households (through remittances or migration possibilities), Vietnam, like many developing countries, is predominantly a rural, primary commodity dependent economy, with almost 70 percent of the population earning a living from agriculture and only 12 percent of the labor force engaged in formal manufacturing. Existing approaches

\footnotetext{
${ }^{9}$ Details of these instruments and the diagnostic tests are described below.
}

${ }^{10} \mathrm{We}$ are grateful to an anonymous referee for highlighting this point. 
that focus on wages also ignore important price effects of trade reform, which are relevant to many of the rural poor who are self-employed in family enterprises, either farms or small-scale industries and services, and the informal sector in general. Studies that focus on the trade impact on the formal manufacturing sector provide only a part of the general effect of trade reforms.

The paper is organized as follows. Section 2 describes the household data sets used in the analysis. In Sections 3 and 4, we discuss our theoretical and empirical framework. The empirical analysis is presented in Section 5. Section 6 concludes the paper.

\section{The Data Sets}

The results presented and discussed in this paper are based on analysis of household survey data from the Vietnam Living Standards Surveys (VLSS) for 1992-93 and 1997-98. These are nationwide surveys, conducted by the Vietnam's General Statistical Office, with financial assistance from the United Nations Development Programme (UNDP) and the Swedish International Development Agency (SIDA) and technical assistance from the World Bank, in 1992-93 (October 1992 to October 1993) and 1997-98 (December 1997 to December 1998). The surveys cover 4,800 households and 120 communes in 1992-93 and 6,000 households and 150 communes in 1997-98, and contain information on household demographics, ethnicity, education, health, economic activities, production and employment, assets and a range of community-level infrastructural and institutional variables. In particular, the VLSS contain valuable data on household-level production and consumption values for over 50 crops, commune-level prices for around 30 food items, and individual-level employment data for over 80 sectors of activity. The VLSS are particularly useful as they follow a panel of 4,303 urban and rural households interviewed in both years. ${ }^{11}$ This feature allows us to track households from before the trade reforms took effect to a period some five years later when some of the doi moi reforms had been implemented, thereby eliminating unobserved differences between households that are fixed over time.

In this paper we refer to the 1992-93 data set, and the variables it contains, as representing the "before reform" baseline and the 1997-98 dataset as the "after reform" position, although the 1997-98 data should be better thought of as reflecting the position of households still undergoing substantial change as reforms continued beyond 2000. Hence our results provide insight into the immediate effects of trade reform in Vietnam.

Although the two VLSS samples are individually representative of the population, the panel is not truly representative of either the whole or the rural population (see Haughton et al., 2001). This is a common feature of panel studies in developing countries (see Deaton, 1997 for a discussion). Our calculations have shown, however, that poverty levels and changes in population shares of panel households across several socio-economic characteristics are similar to results for

\footnotetext{
${ }^{11}$ Nationwide household surveys were also conducted in Vietnam in 2002 and 2004. These surveys did not, however, follow the household panel interviewed in 1992-93 and 1997-98, which limits their interest for our analysis.
} 
the whole sample in each year (Justino and Litchfield, 2003). We are therefore confident that our results provide useful inferences for the rural population of Vietnam.

The analysis developed in this paper is based on the sub-panel of 3,494 rural households. Vietnam is predominantly a rural economy: 78 percent of all households in Vietnam in 1997-98 lived in rural areas (80 percent in 1992-93) and 61 percent of all Vietnamese households were employed in the agriculture sector in 1997-98 (65 percent in 1992-93). The decision to analyze rural households only is further supported by the fact that the key economic reforms implemented in Vietnam (reform of rice pricing and rice trade) were aimed at the rural sector. ${ }^{12}$

We focus in this paper on annual household expenditure per capita ${ }^{13}$ as our welfare indicator and apply a general food and non-food poverty line estimated by the World Bank (World Bank, 2000). Although the VLSS contain some income data, it has proved difficult to construct reliable income estimates for rural households where much income is in-kind. Furthermore, consumption data generally reflects households' permanent income more accurately, and is thus more appropriate for poverty analysis in developing countries where agricultural income is likely to fluctuate during the year and where few households are found in permanent wage employment. ${ }^{14}$ In addition, household income data is relatively scarce in low-income developing countries, where household surveys often serve the dual purpose of measuring living standards as well as providing consumption weights for price indices, so focusing on the expenditure data in the VLSS maintains a broader relevance for analysis of other country data sets.

We define a household to be poor if annual household consumption expenditure per capita is below a poverty line of 1,160 thousand dongs per person per year in 1992-93 and 1,790 thousand dongs per person per year in 1997-98. ${ }^{15}$

\section{Modeling Poverty Dynamics}

Poverty functions are often criticized on the grounds that they introduce measurement errors by using arbitrarily defined poverty lines. Reducing a

\footnotetext{
${ }^{12}$ Our analysis does not consider movements between the rural and urban sectors. Although rural-to-urban migration is undoubtedly an important phenomenon, the VLSS do not track households that migrate. The VLSS do, however, have data on remittances that will be used in our analysis (see Section 5), as these have become an important source of household income in Vietnam during the later 1990s (Dang and Le, 2002).

${ }^{13}$ Lanjouw and Lanjouw (2001) show that the relationship between consumption expenditure/ poverty and household demographic variables may not be robust to the use of equivalence scales so we also tested for sensitivity of our results to the use of an alternative equivalence scale. Expenditure per equivalent adult was calculated using the WHO equivalence scale of 1 for adults and 0.65 for children. We also adjusted the poverty line used to define the four poverty transition outcomes so that it reflects per adult equivalent expenditures. To do this we multiplied the poverty line by 2,800/2,100 (which represents the calorie needs of an adult over the calorie needs of an average person). Results did not differ qualitatively between the two specifications of the welfare indicator, so we present here only the per capita results. Further details are available from the authors.

${ }^{14}$ Gallup (2004) estimates that 24 percent of men and 13 percent of women in rural areas in Vietnam in 1992-93 were in wage employment, while the numbers for 1997-98 were, respectively, 26.3 percent and 12.7 percent.

${ }^{15}$ The values are based on the cost of a basket of food items that provide the minimum amount of 2,100 calories per person per day plus a non-food component. For a detailed discussion of poverty measurement issues in Vietnam, see Litchfield and Justino (2004).
} 
continuous variable, such as household expenditure, to a qualitative variable may "throw away" information on the variation in the dependent variable with respect to the variation in explanatory variables (see Deaton, 1997 for discussion). This is a particularly serious problem if large numbers of households are concentrated around the poverty line.

However, consumption and earnings functions which impose constant parameters across the entire consumption distribution, limit their application to the analysis of the impact of economic shocks on household poverty transitions when the determinants of household welfare have different returns to the poor and the non-poor. In fact, it is possible to have situations in which some households may experience decreases in consumption expenditure without becoming poor, as well as situations in which poor households benefit from improvements in living standards but do not move above the poverty line. In this section, we compare and contrast consumption expenditure and poverty functions and assess the adequacy and usefulness of each model for the analysis of the impact of trade shocks on household poverty dynamics.

On the consumption side, we draw on a model proposed by Dercon (2004) to analyze poverty dynamics in Ethiopia between 1989 and 1995 using, as we do, micro-level panel data. The model is based on standard empirical dynamic growth models as in Mankiw et al. (1992) and Barro (1991):

$$
\ln y_{i t}-\ln y_{i t-1}=\alpha+v_{i}+\beta y_{i t-1}+\delta X_{i t}+\varepsilon_{i t}
$$

where $y_{i t}$ is the level of per capita output in year $t, \alpha$ is a common source of growth across all households, $v_{i}$ represents the household specific fixed effects, $X_{i t}$ are household variables that vary across time and $\varepsilon_{i t}$ is a stochastic error term with zero mean. For the case of Vietnam, the variable on the left-hand side of (1) can be represented by the difference between the logarithmic function of household consumption expenditure in 1992-93 and 1997-98. Assuming a Cobb-Douglas production function for output, dependent on capital, labor and human capital, and constant returns to scale, (1) can be written as:

$$
\ln y_{i t}-\ln y_{i t-1}=\alpha+v_{i}+\gamma \ln k_{i t-1}+\eta \ln h_{c t-1}+\delta X_{i t}+\varepsilon_{i t}
$$

where $k_{i}$ represents the household level of capital per capita and $h_{c}$ is a vector of commune or region levels of capital (infrastructure, institutions and so forth) (Dercon, 2004).

One important limitation of (2) is that it does not allow for the effects of economic shocks on consumption expenditure growth. Shocks can be accounted for once a stationary error term is introduced into (2) but this will not allow for the possibility of shocks having persistent effects. Dercon proposes a modification to (2) in order to account for the effect of economic shocks on economic growth. He assumes the existence of a multiplicative risk, $S_{i t}$, which can be idiosyncratic or common to all households in a particular commune or region. Dercon argues that it is possible to introduce risk into equations (1) and (2) as a control for shocks without adding any further distributional assumptions about the shock. This risk variable can also be used to analyze the persistence of shocks across time when 
sufficient data is available for a long period of time. Equation (3) illustrates this effect. ${ }^{16}$

$$
\text { (3) } \quad \ln y_{i t}-\ln y_{i t-1}=\alpha+v_{i}+\gamma \ln k_{i t-1}+\eta \ln h_{c t-1}+\theta\left(\ln S_{i t}-\ln S_{i t-1}\right)+\delta X_{i t}+\varepsilon_{i t} \text {. }
$$

Dercon (2004) uses model (3) to investigate the impact of weather and illness shocks on economic growth. This framework can however be easily applied to assess the impact of other household economic shocks, such as those caused by the trade reforms discussed above. By identifying events associated with the price and employment transmission mechanisms or channels, we can use the model to determine the effects of those reforms on changes in real household consumption expenditure.

Models such as (3) can have important applications in determining the impact of economic shocks on changes in household welfare characteristics and returns to those characteristics. However, as discussed above, these models have restricted use in assessing poverty transitions if coefficients for the various explanatory variables are not constant across the entire consumption distribution. One way of avoiding this limitation is to model poverty dynamics directly. Movements in and out of poverty between two time periods can be modeled using discrete outcome models.

One such model is the multinomial logit models of poverty dynamics, as used by Glewwe et al. (2002) for their study of poverty dynamics in Vietnam. Poverty transitions between two periods can be divided into four mutually exclusive outcomes: (i) being poor in both periods (PP); (ii) being non-poor in the first period and poor in the second period (NPP); (iii) being poor in the first period and non-poor in the second period (PNP); and (iv) being non-poor in both periods (NPNP). The Small-Hsiao test can then be used to assess independence between the four outcomes (see Small and Hsiao, 1985) ${ }^{17}$ and it is very straightforward to test the robustness of results to where the poverty line is drawn.

The multinomial logit model determines the probability that household $i$ experiences one of the $j$ mutually exclusive outcomes (as above). This probability is given by:

$$
P\left(Y_{i}=j\right)=\frac{e^{\beta_{j} x_{i}}}{1+\sum_{k=1}^{J} e^{\beta_{k} x_{i}}}, \text { for } j=1,2, \ldots, \mathbf{J} \quad \text { and } \quad P\left(Y_{i}=0\right)=\frac{1}{1+\sum_{k=1}^{J} e^{\beta_{k} x_{i}}}
$$

In the equations above, $Y_{i}$ is the outcome experienced by household $i, \beta_{k}$ are the set of coefficients to be estimated and $x_{i}$ includes aspects specific to the individual household as well as to the choices. $\beta_{0}$ has been set to zero (i.e. remaining poor in both periods) in order to identify the model (i.e. the Theil normalization). All other $\beta_{k}$ are estimated in relation to this benchmark.

From the model above, we can compute $J$ log-odds ratios $\ln \left[P_{i j} / P_{i 0}\right]=\beta_{j}^{\prime} x_{i}$. The log-odds ratios (also called relative risk ratios) can be normalized on any other

\footnotetext{
${ }^{16}$ This is a simplification of Dercon's (2004) model as we do not have enough data points to analyze the persistence of shocks for more than two time periods.

${ }^{17}$ Wills (1987) argues that the Small-Hsiao test is favored to the more conventional Hausman test.
} 
probability, which will yield $\ln \left[P_{i j} / P_{i 0}\right]=x_{j}^{\prime}\left(\beta_{j}-\beta_{k}\right)$ (see Greene, 2000). For ease of presentation $\ln \left[P\left(Y_{i 1}=2\right) / P\left(Y_{i 0}\right)=0\right]$ and $\ln \left[P\left(Y_{i 1}=1\right) / P\left(Y_{i 0}=3\right)\right]$ are calculated. These measure, respectively, the risks of a household escaping poverty relative to remaining poor, and of falling into poverty relative to remaining non-poor. ${ }^{18}$

The poverty transition results can be used to provide a decomposition of the overall probability of escaping or entering poverty by each of the explanatory variables, as follows:

$$
S_{Y}=\frac{\beta_{i} \cdot \sum_{j=1}^{n} x_{i j}}{\sum_{i=1}^{k} \sum_{j=1}^{n} \beta_{i} x_{i j}}
$$

where $S$ is the share of the overall probability of outcome $Y, n$ is the total number of observations in the panel, $k$ is the total number of poverty dynamic outcomes, $X_{i j}$ are the values of the explanatory variables for household $i$ in period $j$ and $\beta_{i}$ are the coefficients obtained from the MNL regression models (not the rrr).

In addition to estimating the continuous consumption growth model described in (3) and the multinomial logit model of (4) we examine the determinants of changes in consumption expenditure for specific quantiles of the initial, 1992-93, expenditure distribution. One of the criticisms often levied at the type of continuous consumption growth model described in (3) above is that effects of changes in the independent variables are estimated at the mean of the dependent variable and there is much evidence to support the view that effects at the mean may not be representative of effects at other parts of the distribution, either because the mean is strongly affected by outliers or because of behavioral differences across the distribution. For example, it is plausible that the effect of an extra child may have a much stronger impact on living standards at the bottom of the distribution, than at the top. However, a quantile regression approach has less intuitive appeal in the particular context of our dependent variable, the change in consumption: quantile regression estimates would infer the effects of the independent variables at different quantiles of the distribution of the change in consumption over time, i.e. for households that experience small changes compared to those that experience large changes, regardless of their initial position.

Hence, rather than apply a conventional quantile regression approach, we adapt a sample selection method first suggested in Stewart (1983) and later applied by Main and Reilly (1993). ${ }^{19}$ By splitting the sample into quantiles of the 1992-93 distribution of consumption and at the same time controlling for selection into

\footnotetext{
${ }_{18}^{18} e^{\beta_{j}^{\prime} x_{i}}$ is the relative risk ratio for a unit change in the variable $x$ : a relative risk ratio (rrr) of less than one means that an increase in variable $x$ increases the probability that the household is in the base category, i.e. the category identified in the denominator, whereas an $r r r$ of more than one implies an increase in the probability of the household being in the alternative state, i.e. that identified in the numerator.

${ }^{19}$ Stewart (1983) demonstrated that information on the censoring limits could be used to infer the scale of a latent variable application; Main and Reilly (1993) applied it by modeling the wage determination process of employees in small, medium and large firms while controlling for selection into employment in firms of different size.
} 
those quantiles, we can then examine whether initially poorer households responded in the same ways or to the same extent as households further up the distribution. We can therefore test the assumption that coefficients are constant across the initial consumption expenditure distribution, namely whether returns to initial conditions and responses to the trade-induced change variables, differ between, for example, the poorest third, the middle third and the richest third of households. ${ }^{20}$

In order to examine whether households at different positions of the conditional consumption expenditure distribution in the initial year experienced different improvements in their expenditure level between 1997-98 and 1992-98, we specify the three following equations:

$$
\begin{aligned}
& \Delta \ln y_{0 i}=x_{0 i}^{\prime} \alpha_{0}+\eta_{0 i} \\
& \Delta \ln y_{1 i}=x_{1 i}^{\prime} \alpha_{1}+\eta_{1 i} \\
& \Delta \ln y_{2 i}=x_{2 i}^{\prime} \alpha_{2}+\eta_{2 i}
\end{aligned}
$$

where $\Delta \ln y_{j i}$ is the difference in log consumption expenditure between the two years, $\boldsymbol{x}$ is a matrix of expenditure determining variables, and the subscripts 0,1 , 2 denote the bottom, middle, and top terciles of the household expenditure distribution in the initial year.

Estimating equations (6a) to (6c) using OLS will however result in biased estimates as the sample is truncated at the tercile thresholds. Instead of using a probit model for the selection process, as suggested by Heckman (1979), an ordered probit model provides an appropriate framework through which the attachment of household to each tercile of the consumption expenditure can be examined. A latent dependent variable can be defined as:

$$
\begin{array}{rlrl} 
& z_{i}^{*}=\boldsymbol{w}_{\boldsymbol{i}}^{\prime} \partial+\mu_{i} \\
z_{i}=0 & \text { if } & -\infty \leq z^{*} \leq 0 \\
=1 & \text { if } & 0 \leq z^{*} \leq \varpi \\
=2 & \text { if } & \varpi \leq z^{*} \leq+\infty
\end{array}
$$

where $\boldsymbol{z}$ is unobservable, $\boldsymbol{w}$ contains the set of determining variables, and the dependent variables $\Delta \ln y_{j i}$ in equations (6a) to (6c) are only observed when $z=j$ with $j=0,1,2$.

The estimation of this model is then estimated through two stages that follow Heckman (1979) and Greene (1981), which provide the standard results for the case in which $\mathbf{J}=1$ (i.e. the simple probit model). In the first stage, the ordered probit model (6) is estimated using MLE for all observations to obtain the selection bias correction terms. In the second stage, the tercile expenditure equations (6a) to (6c), augmented by the selection bias correction terms, will be estimated

\footnotetext{
${ }^{20} \mathrm{We}$ chose terciles, i.e. thirds, of the initial distribution to ease computation issues as well as to improve cell sizes.
} 
using OLS. The covariance matrix of the estimates then needs to be corrected using the procedure suggested by Greene (1981). ${ }^{21}$

The key to the application of the framework is to construct a set of identified variables that affect the attachment to each tercile of the household expenditure distribution in the initial period but not the changes in the consumption expenditure level between the two years. In our case, the identified variables include a set of household type dummies (i.e. household with one or two adults, household with parent(s) and one child, household with parent(s) and two children, household with parent(s) and three or more children, three-generation households, and other household structures) and a set of dummies that control for geographical types of communes (i.e. coastal, inland delta, low mountain, medium mountain, and high mountain).

\section{Model Specification}

The dependent variables used are firstly the change in annual consumption expenditure per capita between 1992-93 and 1997-98 for the continuous approaches (all measured in natural logarithms), and secondly the four poverty transition outcomes (PP, NPP, PNP, NPNP) for the discrete poverty approach. ${ }^{22}$

We start in each case by specifying a basic model that contains only variables that measure initial conditions, following very closely the specification used by Glewwe et al. (2002). This is partly so that we can remove all possibility of endogeneity issues, but also to allow us to examine parameter stability when the variables that capture trade reforms are introduced. The initial conditions capture the following characteristics:

- A set of individual characteristics, including age and squared age (in years), gender, ethnicity, ${ }^{23}$ education and labor market status of the household head, ${ }^{24}$ the number of days work of the head lost to illness in the month preceding interview and the education of the spouse.

- A set of household characteristics, including the number of adults and children in the household, and the proportion of household workers employed in any of the four export sectors (seafood, food processing, textiles and footwear).

\footnotetext{
${ }^{21}$ See Main and Reilly (1993) for more details.

${ }^{22} \mathrm{We}$ tested the sensitivity of results to the poverty thresholds by varying the poverty lines in each year by 10 percent in both directions, presented in full in Justino and Litchfield (2003). We also repeated all the analysis for changes in per adult equivalent consumption but found very little difference in estimates and thus only report here the per capita results. This result may be because economies of scale in household consumption are small, given that much of food expenditure is on rice and/or to the relatively small variation in household size among the majority Kinh population.

${ }^{23}$ Earlier specifications also included religion, with dummies for Buddhists and other religions, but we have dropped this variable because it is not clear why religion should exert an effect on welfare changes, and it is in any case correlated with ethnicity and region dummies.

${ }^{24}$ The occupation variable was constructed using the list of profession codes provided in the surveys. We have divided the occupation variable into white collar (scientists, architects, lawyers, economists, academics, clerical workers, etc), sales and services (retail and wholesale workers, salesmen, hotel managers and workers, hairdressers, etc), agriculture (farmers, forestry workers, fishermen, etc), production (miners, masons, food processing workers, shoemakers, painters, etc) and those not working which also includes the unemployed.
} 
- A set of agricultural production characteristics, including area of land used for purposes other than rice (as a measure of agricultural diversification) and the area of irrigated land (both measured in 1000s of square meters per capita), the quantity of total fertilizers (in $\mathrm{kg}$ per square meter) used for rice cultivation in the 12 months prior to interview, and the household's rice productivity level (kilos of rice harvested per square meter of land). We also include here a dummy for whether the household was a net rice producer in 1992-93 and for whether the household had any extended land rights in $1992-93 .^{25}$

- A set of variables that capture assets and other sources of income, including a dummy for whether the household receives remittances, ${ }^{26}$ the value of net assets of the household and a dummy for whether the household has access to electricity as a measure of the overall condition of the dwelling.

- A set of commune level infrastructure dummies for existence of a paved road, primary and secondary schools, post office, daily market, food shop and a community clinic.

- A set of regional and interview controls.

So far, our specification follows Glewwe et al. (2002), but we make a number of useful enhancements to the model. Apart from specifying education in terms of the highest level of education attained, rather than number of years as in Glewwe et al., we also incorporate additional variables that capture initial conditions that would seem likely to affect the ability of households to escape from poverty, namely employment of household members in an export sector, land rights, use of fertilizer and receipt of remittances, which have not previously been exploited. Hence our work potentially represents an advance on existing Vietnam work.

We build further on Glewwe et al. by adding a small number of "change" variables $^{27}$ that capture events associated with the price and employment transmission channels described above. These are the change in the price of rice, the change in the share of workers employed in the four main export sectors and changes in rice productivity. As described in the introduction, we initially specify these variables at the household level (using unit values in the case of household rice prices ${ }^{28}$ ). In response to the strong possibility of endogeneity between these

\footnotetext{
${ }^{25}$ One aspect of the doi moi policies was to allow communes greater flexibility in their allocation of land among households, and some households were given extended rights to exchange, transfer, lease, inherit and mortgage land which are likely to have increased their access to credit, output and overall living standards. However, certification of land use rights was very slow in the 1990s and only accelerated after the updated Land Law in 2003. Thus while it is likely that households having land use rights may have had greater flexibility to diversify within agriculture, it is unlikely that in the time-frame under analysis here, having extended land use rights would have any significant impacts on households ability to raise credit etc.

${ }^{26}$ Ideally we would have incorporated remittances as a continuous variable, but only a few households reported the value of remittances.

${ }^{27} \mathrm{An}$ earlier version of this paper also included non-trade shocks such as an illness, birth or death of a household member, receipt of migrant remittances and weather shocks. We dropped these from this version because (a) there is likely to be strong endogeneity between some of these variables and changes in poverty status, and (b) some of the external non-trade shocks, such as weather are highly correlated with region.

${ }^{28}$ Unit values of rice and paddy were derived as the weighted average of the ratio between the total value of ordinary and glutinous rice (bought and sold) and their total quantities. Missing unit values for rice consumption were replaced by the commune mean unit value. Rice was converted to paddy in $1997-98$ by a factor of 0.66 , following VLSS (2001).
} 
variables and the dependent variable, we adopt a 2SLS approach and instrument for them using several sets of instruments. ${ }^{29}$

We start with the most simplified set that is a parsimonious group of demographic variables (shares of men, women, boys and girl of different ages), household education levels (share of household members with educational levels from upper secondary and higher), and household employment allocation (share of household members working in agriculture as primary occupation), and agricultural intensity (total fertilizer used, in $\mathrm{kg}$ ) in 1992-93. This basic set is expanded to capture initial conditions as well as changes in infrastructure, availability of land, average usages of fertilizers, availability of export sector employment, and access to public services such as job creation programs and agricultural extension at the commune level. Three different tests are performed on the eight resultant sets of instruments to examine if the 2SLS approach is successful in addressing the potential endogeneity problem. We use an F-test for instrumental relevance, Sargan's LM test for instrument validity and finally the Hausman exogeneity test. The results are shown in Table A2 and generally demonstrate that the endogeneity problem is not resolved by any of these sets of instruments. This reflects the difficulty in finding relevant and valid instruments, given the data available in the VLSS, which are similar to other household surveys.

In response to the probable presence of endogeneity, we replace the household level changes with a set of commune level changes in the share of export sector employment, the total number of households as a measure of commune size, the average rice productivity (i.e. averaged across all rice producing households), and the price of rice at the commune level, as reported in the commune questionnaires.

With regard to the multinomial model, specification tests confirm that MNL models are adequate to investigate the poverty dynamic outcomes with our data. ${ }^{30}$

\section{EMPiRical Results}

We begin by discussing the results for the continuous consumption growth models represented by equation (3) for changes in per capita consumption expenditure in the means regression. Results for the base model (that containing only initial 1992-93 values) are shown in column 1, and for the extended model incorporating the "changes" as described above in column 2 of Table $2 .{ }^{31}$

The results from the base model, i.e. that incorporating only initial characteristics of households and their communes, yields similar results to existing studies

\footnotetext{
${ }^{29}$ In fact, in the absence of any well defined theory we did not attempt to instrument for household level rice unit values, and conducted the 2SLS approach for changes in rice productivity and changes in share of household workers employed in the export sectors.

${ }^{30}$ This is based on the Small-Hsiao test for the IIA property of the MNL models, and the Wald test for whether any of the two outcomes can be combined (see Wills, 1987). Full details are available from the authors upon request.

${ }^{31} \mathrm{We}$ also applied a median regression approach to the consumption growth models to examine whether our analysis is sensitive to the presence of outliers (see Koenker, 2005). The estimates obtained at the median are essentially the same as those obtained at the mean by the OLS. This can be taken to suggest that outliers are not an issue that needs to be resolved with our data. The results from the median regressions are not discussed here for brevity. Full details are available from the authors upon request.
} 
TABLE 2

Determinants of Changes in Per Capita Household Consumption Expenditures

\begin{tabular}{|c|c|c|}
\hline & Baseline Model & Extended Model \\
\hline \multicolumn{3}{|l|}{ Demographic/health/ethnic } \\
\hline Head belongs to an ethnic minority & $-0.0696 * * *$ & $-0.0691 * * *$ \\
\hline Head is male & -0.0215 & -0.0213 \\
\hline Head age & 0.0035 & 0.0035 \\
\hline Head age squared & -0.0024 & -0.0023 \\
\hline Head has no spouse & 0.0233 & 0.0218 \\
\hline Number of days lost to illness by head & $-0.0601 * *$ & $-0.0603 * *$ \\
\hline Number of adults in household & $0.0257 * * *$ & $0.0251 * * *$ \\
\hline Number of children in household & $0.0468 * * *$ & $0.0477 * * *$ \\
\hline \multicolumn{3}{|c|}{ Human capital (reference category is not completed primary or no education) } \\
\hline Head completed primary school & -0.0092 & -0.0073 \\
\hline Head completed lower secondary school & $0.0441 *$ & $0.0451^{* *}$ \\
\hline Head completed upper secondary school & $0.0766^{*}$ & $0.0803^{* *}$ \\
\hline Head completed technical/university & $0.0545^{*}$ & $0.0540^{*}$ \\
\hline Spouse completed primary school & 0.0275 & 0.0313 \\
\hline Spouse completed lower secondary school & -0.0013 & -0.0025 \\
\hline Spouse completed upper secondary school & -0.0711 & $-0.0792 *$ \\
\hline Spouse completed technical/university & 0.0017 & 0.0015 \\
\hline \multicolumn{3}{|l|}{ Labor market (reference category is white collar) } \\
\hline Head employed in agriculture & -0.0151 & $-0.0718^{*}$ \\
\hline Head employed in sales & $-0.0574 * *$ & -0.0138 \\
\hline Head employed production & -0.0206 & -0.0205 \\
\hline Head not working & -0.0213 & -0.0197 \\
\hline Employment share in export sector & $0.1582 * * *$ & $0.1264 * * *$ \\
\hline \multicolumn{3}{|l|}{ Agricultural production } \\
\hline Non-rice land $\left(1,000 \mathrm{~m}^{2}\right)$ & $-0.0066^{* * *}$ & $-0.0063^{* * *}$ \\
\hline Quantity of fertilizers $\left(\mathrm{kg} / \mathrm{m}^{2}\right)$ & $-0.1107 * * *$ & $-0.1153 * * *$ \\
\hline Irrigated land pc $\left(1,000 \mathrm{~m}^{2}\right)$ & $-0.0463^{* * *}$ & $-0.0503 * * *$ \\
\hline Net rice producer dummy & 0.0032 & -0.0046 \\
\hline Rice productivity & 0.0283 & 0.0440 \\
\hline \multicolumn{3}{|l|}{ Household assets/other income } \\
\hline Household has extended land rights in $92-93$ & $0.0671 *$ & $0.0669^{* *}$ \\
\hline Household received remittances in $92-93$ & $0.0296^{*}$ & $0.0257 *$ \\
\hline Net assets (million VND) & -0.0012 & -0.0011 \\
\hline Household has access to electricity & -0.0033 & 0.0035 \\
\hline \multicolumn{3}{|l|}{ Commune infrastructure } \\
\hline Road & $0.1685^{* * *}$ & $0.1543^{* * *}$ \\
\hline Primary school & $0.2914^{* * *}$ & $0.2746^{* * *}$ \\
\hline Lower secondary school & $-0.0920 * * *$ & $-0.0779 * * *$ \\
\hline Upper secondary school & -0.0107 & -0.0285 \\
\hline Post office & $-0.0439 * *$ & $-0.0323 *$ \\
\hline Daily market & -0.0103 & -0.0083 \\
\hline Food shop & 0.0160 & 0.0177 \\
\hline Community clinic & 0.0160 & -0.0020 \\
\hline \multicolumn{3}{|l|}{ Geographic (reference region is North Central) } \\
\hline Northern Uplands & -0.0290 & 0.0962 \\
\hline Red River Delta & $0.0661 * * *$ & 0.0413 \\
\hline South Central Coast & $-0.0974 * * *$ & $-0.1034 * *$ \\
\hline Central Highlands & $0.0558 * * *$ & $0.0989 *$ \\
\hline South East & $0.1497 * * *$ & $0.1915^{* * *}$ \\
\hline Mekong River Delta & $-0.1242 * * *$ & $-0.0999^{* * *}$ \\
\hline \multicolumn{3}{|l|}{ Seasonality (reference season is 1 st quarter) } \\
\hline 2nd quarter & $0.0777 * * *$ & $0.0704^{* * *}$ \\
\hline 3rd quarter & $-0.0642 * * *$ & $-0.0862 * * *$ \\
\hline 4 th quarter & $-0.0439 * *$ & $-0.0484^{* *}$ \\
\hline
\end{tabular}


TABLE 2 (continued)

\begin{tabular}{lcc}
\hline \hline & Baseline Model & Extended Model \\
\hline $\begin{array}{l}\text { Trade reform variables, commune level } \\
\text { Change in employment share in export } \\
\text { sector }\end{array}$ & - & $0.2741^{* *}$ \\
$\begin{array}{l}\text { Change in number of households in } \\
\quad \text { commune }\end{array}$ & - & $0.0229^{*}$ \\
Change in price of ordinary rice & - & $0.0619^{* * *}$ \\
Change in rice productivity in commune & - & $0.4039^{* * *}$ \\
Constant term & $-0.2297^{* *}$ & $-0.3122^{* *}$ \\
Adjusted $\mathrm{R}^{2}$ & 0.1244 & 0.1323 \\
Number of observations & 3,494 & 3,494 \\
\hline
\end{tabular}

Notes: ***Significant at $1 \%$ level, **significant at $5 \%$ level, *significant at $10 \%$ level.

on Vietnam. ${ }^{32}$ Lower consumption growth rates are experienced by households with a head belonging to an ethnic minority group, suffering an illness at the time of the initial survey or being employed in sales and services, and by households in the Mekong River Delta and in the South Central Coast. Households living in the South East and Red River Delta, which include respectively HCMC and Hanoi as the two largest industrial clusters, benefited from increases in consumption expenditure between 1992-93 and 1997-98, and as expected, households with access to basic infrastructure such as a transportable road and primary schools in the commune were better-off during the doi moi. Like other studies we find some evidence of convergence from the agriculture variables: households with more irrigated rice land per capita, with more intensive use of fertilizer, and with more non-rice agricultural land, had lower growth rates. This suggests that concentration in agriculture in the initial period produces a negative effect on improvement in household welfare over time. Combined with the evidence that having a greater share of workers working in the key export sectors improves changes in consumption, this could suggest that diversifying into non-farm activities is a way out of poverty for land-constrained rural households. Further support for this is provided by the positive sign of the land rights dummy.

Interestingly, being of above average productivity in the initial period, or a net rice producer, did not have a statistically significant effect on consumption growth. One might have expected the initially more productive farmers, or at least those with larger surpluses, to be in a stronger position to benefit from the relaxing of restrictions in the rice sector, the rise in rice prices and fall in key inputs such as fertilizers over the period. We return to this point shortly. However, we do see that having extended land use rights early in the 1990s was important, suggesting that these farmers had greater ability to diversify out of rice, into the "rice, orchard, pond" model of household farm production.

Turning now to column 2 of Table 2 and the model that incorporates changes in key trade-related variables, we see that the results described above using initial conditions only are broadly robust to inclusion of the change variables. Even more importantly, the results suggest that the trade-related change variables exert a

${ }^{32}$ See, for example, Van de Walle and Cratty (2003), Baulch et al. (2004), Swinkels and Turk (2006), World Bank (2000), PTF (2002), and Glewwe et al. (2002). 
material effect on consumption expenditure through both an employment channel and a price channel. On average and ceteris paribus, a 10 percent rise in the commune ratio of export employment over time increases the average household expenditures by nearly 2.7 percent. Our estimates also reveal that, holding other things equal, a 10 percent increase in the ordinary rice price at the commune level produces almost 1 percent higher real consumption expenditure. Finally, we see that households living in communes where rice productivity increased, experienced very strong increases in consumption. Taken together, these results suggest that opportunities provided by trade liberalization of greater employment opportunities outside of agriculture in export-sectors, together with the creation of favorable economic conditions for rice producers, had very strong and positive welfare effects.

We report the estimates for the poverty dynamics models in Table 3 . The results from both the baseline model (initial levels only) and the extended model (with the commune level changes) are consistent with those of the continuous model. As before, the poverty models show that the probability of escaping poverty relative to remaining poor is higher than average for those individuals belonging to households with better-educated heads and heads employed in whitecollar jobs. Most institution and infrastructure variables seem to have welfareenhancing effects. The exception is access to a post office, which seems to decrease the probability of households escaping poverty and increase the probability of households falling into poverty. This apparently perverse effect may be related to particular characteristics of communes that have post offices: most of these are in the Mekong River Delta, where a relatively large percentage of households fell into poverty (Table A1 in the Appendix). The result also demonstrates a geographical difference in poverty dynamics. ${ }^{33}$ Households in the Southeast, Mekong River Delta, and Central Highlands are more likely to move out of poverty. The movement out of poverty in the Mekong River Delta and Central Highlands might be linked to the boom of rice and coffee exports respectively during the first half of the $1990 \mathrm{~s} .{ }^{34}$ On the other hand, ethnic minorities, as well as households with younger or relatively poorly educated household heads, those not receiving remittances or whose head of household had been absent from work through illness, were more likely to having fallen into poverty in Vietnam between 1992-93 and 1997-98.

The poverty transition model shows further that household poverty dynamics in Vietnam between 1992-93 and 1997-98 were also significantly affected by trade reform through mainly an employment and a price channel. The models show that the higher the share of household members employed in the main export industries in the initial period, the larger the probability of having escaped poverty in relation to remaining poor in both years. This positive effect of the expansion in export employment is also observed for the change in the average share of export sector employment at the commune level. There is strong evidence to support the hypothesis that changes in poverty were affected by opportunities created in the export

\footnotetext{
${ }^{33} \mathrm{We}$ interacted the trade variables with the regional dummies, but these interactive variables performed poorly in the regression models. This is probably due to the fact that part of the location effect is already controlled by the commune-level infrastructure conditions and the adjustment of consumption expenditure by regional price indices. We do not discuss the results here for brevity.

${ }^{34}$ It should be noted that the effect of rice and coffee exports changed by the late 1990s due to worsening external environment, especially after the collapse of the world coffee price in 1998.
} 
TABLE 3

Poverty Dynamics in Vietnam: Multinomial Logit Models

\begin{tabular}{|c|c|c|c|c|}
\hline & \multicolumn{2}{|c|}{ Baseline Model } & \multicolumn{2}{|c|}{ Extended Model } \\
\hline & $\mathrm{P} \rightarrow \mathrm{NP}$ & $\mathrm{NP} \rightarrow \mathrm{P}$ & $\mathrm{P} \rightarrow \mathrm{NP}$ & $\mathrm{NP} \rightarrow \mathrm{P}$ \\
\hline \multicolumn{5}{|l|}{ Demographic/health/ethnic } \\
\hline Head belongs to an ethnic minority & $0.4378 * * *$ & $2.5166^{* * *}$ & $0.4460 * * *$ & $2.3201 * * *$ \\
\hline Head is male & 0.9158 & 0.9572 & 0.9169 & 0.9570 \\
\hline Head age & $1.1153^{* * *}$ & $0.8731^{* * *}$ & $1.1042 * * *$ & $0.8758 * * *$ \\
\hline Head age squared & $0.9197 * * *$ & $1.1172 * *$ & $0.9211 * * *$ & $1.1139 * * *$ \\
\hline Head has no spouse & 1.0339 & 0.9543 & 1.0475 & 0.9917 \\
\hline Number of days lost to illness by head & 1.2893 & $2.0471 * * *$ & 1.2525 & $1.9812 * *$ \\
\hline Number of adults in household & 0.9992 & $1.1316^{*}$ & 0.9948 & $1.1271^{*}$ \\
\hline Number of children in household & $0.7775^{* * *}$ & 0.8743 & $0.7751 * * *$ & $0.8656^{*}$ \\
\hline \multicolumn{5}{|c|}{ Human capital (reference category is not completed primary or no education) } \\
\hline Head completed primary school & $2.0242 * * *$ & 0.8333 & $2.0579 * * *$ & 0.8349 \\
\hline Head completed lower secondary school & $2.8828^{* * *}$ & $0.5650^{* *}$ & $2.9707 * * *$ & $0.5554 * * *$ \\
\hline Head completed upper secondary school & $2.9456 * * *$ & $0.2777 * *$ & $3.0887 * * *$ & $0.2736 * * *$ \\
\hline Head completed technical/university & $2.2180^{* * *}$ & $0.3240 * * *$ & $2.2184 * * *$ & $0.3357 * * *$ \\
\hline Spouse completed primary school & 1.1221 & $0.6089 *$ & 1.144 & $0.6121^{*}$ \\
\hline Spouse completed lower secondary school & 1.1382 & 1.0181 & 1.1652 & 1.0147 \\
\hline Spouse completed upper secondary school & 1.3418 & 1.86 & 1.3438 & 2.1726 \\
\hline Spouse completed technical/university & $2.5245^{* * *}$ & $0.5232 * *$ & $2.6295 * * *$ & $0.502 *$ \\
\hline \multicolumn{5}{|l|}{ Labor market (reference category is white collar) } \\
\hline Head employed in agriculture & $3.5446^{* * *}$ & 0.6994 & 0.4948 & 0.6845 \\
\hline Head employed in sales & $1.6158^{*}$ & $0.3763 * *$ & $0.3035 * * *$ & $0.3782 * *$ \\
\hline Head employed production & 1.2359 & 0.6827 & $0.3835^{* *}$ & 0.6692 \\
\hline Head not working & $0.6921 *$ & 0.7103 & $0.2045^{* * *}$ & 0.7277 \\
\hline Employment share in export sector & 1.9747 & 1.4251 & $2.1400 *$ & 1.2238 \\
\hline \multicolumn{5}{|l|}{ Agricultural production } \\
\hline Non-rice land $\left(1,000 \mathrm{~m}^{2}\right)$ & $1.0360^{* * *}$ & 0.9743 & $1.0385 * * *$ & $0.9714^{*}$ \\
\hline Quantity of fertilizers $\left(\mathrm{kg} / \mathrm{m}^{2}\right)$ & $3.1560^{* * *}$ & 0.8753 & $3.3588 * * *$ & 0.8922 \\
\hline Irrigated land per capita $\left(1,000 \mathrm{~m}^{2}\right)$ & 1.1174 & 1.0708 & 1.0995 & 1.0655 \\
\hline Net rice producer dummy & 0.9618 & 1.1373 & 0.9452 & 1.1671 \\
\hline Rice productivity & $2.3780^{*}$ & 0.8996 & $2.3941^{*}$ & 0.8438 \\
\hline \multicolumn{5}{|l|}{ Household assets/other income } \\
\hline Household has extended land rights in 1992-93 & 1.1264 & $0.4053^{* * *}$ & 1.1107 & $0.3961 * * *$ \\
\hline Household received remittances in 1992-93 & 1.1656 & $0.6852 *$ & 1.1481 & 0.7161 \\
\hline Net assets (million VND) & 0.9807 & 0.9764 & 0.9810 & 0.8931 \\
\hline Household has access to electricity & $1.4412 * * *$ & $0.3942 * * *$ & $1.4148 * * *$ & $0.3910 * * *$ \\
\hline \multicolumn{5}{|l|}{ Infrastructure } \\
\hline Road & $1.6441 * * *$ & 0.8993 & $1.6106 * * *$ & 1.1562 \\
\hline Primary school & 0.8731 & 0.6620 & 0.8957 & 0.7185 \\
\hline Lower secondary school & 0.8242 & 0.9020 & $0.7543^{*}$ & 0.7727 \\
\hline Upper secondary school & $1.3537 * *$ & 0.8261 & 1.2534 & 0.9349 \\
\hline Post office & $0.5661^{* * *}$ & $1.5827 * *$ & $0.5542 * * *$ & $1.6725^{* *}$ \\
\hline Daily market & $1.3192 * *$ & 1.1657 & $1.3045^{* *}$ & 1.0538 \\
\hline Food shop & $1.4676^{* * *}$ & $0.6219^{*}$ & $1.5087 * * *$ & $0.5089 * *$ \\
\hline Community clinic & $2.1457 * * *$ & 1.0518 & $1.9615^{* * *}$ & 1.0732 \\
\hline \multicolumn{5}{|l|}{ Geographic } \\
\hline Northern Uplands & 1.0677 & 1.1365 & 1.0462 & 1.1512 \\
\hline Red River Delta & 1.1760 & 0.9988 & 0.8939 & 1.1573 \\
\hline South Central Coast & 1.3063 & $0.5137^{*}$ & 1.0173 & 0.8832 \\
\hline Central Highlands & $2.1016^{* *}$ & $0.2552 *$ & $1.6462 *$ & 0.5411 \\
\hline Southeast & $5.7885^{* * *}$ & $0.1933^{* * *}$ & $4.3282 * * *$ & $0.2709 * * *$ \\
\hline Mekong River Delta & $2.2145^{* * *}$ & $0.5478 *$ & $1.5997 * *$ & 0.7745 \\
\hline
\end{tabular}


TABLE 3 (continued)

\begin{tabular}{|c|c|c|c|c|}
\hline & \multicolumn{2}{|c|}{ Baseline Model } & \multicolumn{2}{|c|}{ Extended Model } \\
\hline & $\mathrm{P} \rightarrow \mathrm{NP}$ & $\mathrm{NP} \rightarrow \mathrm{P}$ & $\mathrm{P} \rightarrow \mathrm{NP}$ & $\mathrm{NP} \rightarrow \mathrm{P}$ \\
\hline \multicolumn{5}{|l|}{ Seasonality } \\
\hline 2nd quarter & 0.9482 & 0.6930 & 1.0251 & 0.7309 \\
\hline 3rd quarter & 1.1053 & 0.8464 & 1.0935 & 1.0077 \\
\hline 4 th quarter & 0.8854 & 0.8862 & 0.8777 & 0.9101 \\
\hline \multicolumn{5}{|l|}{ Trade reform variables, commune level } \\
\hline Change in employment share in export sector & - & - & $4.9122 *$ & 0.0865 \\
\hline Change in number of households in commune & - & - & 0.9244 & $0.7691 * *$ \\
\hline Change in price of ordinary rice & - & - & $1.3101 * * *$ & $0.4835^{* * *}$ \\
\hline Change in rice productivity at commune & - & - & 0.7375 & 1.3075 \\
\hline Adjusted $\mathrm{R}^{2}$ & 0.2079 & 0.2079 & 0.2165 & 0.2165 \\
\hline Number of observations & 3,494 & 3,494 & 3,494 & 3,494 \\
\hline
\end{tabular}

Notes: ${ }^{* * *}$ Significant at $1 \%$ level, ${ }^{* *}$ significant at $5 \%$ level, $*$ significant at $10 \%$ level.

TABLE 4

Decomposition of Poverty Dynamic Effects (\%)

\begin{tabular}{lc}
\hline \hline Variables & $\begin{array}{c}\text { Probability of } \\
\text { Escaping Poverty }\end{array}$ \\
\hline Location, in which & 20.49 \\
Northern Uplands & -5.98 \\
Red River Delta & 7.33 \\
South Central Coast & -1.10 \\
Central Highlands & -4.33 \\
South East & 16.20 \\
Mekong River Delta & 8.37 \\
Ethnicity & -6.21 \\
Demographic/health & -14.52 \\
Human capital & 38.13 \\
Labor market, in which & 15.35 \\
Share of export employment & 6.73 \\
Agricultural production & 16.12 \\
Household assets/other income & 6.81 \\
Infrastructure & 14.23 \\
Seasonality & -6.50 \\
Changes variables at commune level, in which & 16.30 \\
Change in employment share in export sector & 8.17 \\
Change in price of ordinary rice & 2.97 \\
\hline
\end{tabular}

Source: Own calculations based on the estimates obtained from the MNL models as in Table 3.

sector by the trade reforms, while improvements in agriculture conditions have allowed the freeing of household labor into more profitable sectors. Furthermore, the effect of trade reforms was also felt strongly through a price channel. Our estimates reveal that increases in the commune average price of ordinary price exert a positive effect on the probability of escaping poverty.

Before discussing the final set of regressions for each tercile, i.e. equations (6a) to (6c), we digress slightly and examine the results of the decomposition of poverty transitions, described above. Table 4 presents the decomposition of the probability of a household escaping poverty using the regression coefficients for the multinomial logit model. The results show that trade-related household events did have a 
significant direct contribution to poverty reduction in Vietnam between 1992-93 and 1997-98. In particular, changes in trade-related variables account for nearly 18 percent of the probability of rural Vietnamese households having escaped from poverty in 1997-98, and this trade effect on escaping poverty is largely attributed to the employment channel (which makes up nearly 15 percent). The contribution of trade effects on rural poverty reduction is compatible to those of infrastructure, and agricultural production.

Finally, we discuss the results from the estimates of equations (6a) to (6c), i.e. the regressions of the change in consumption for each third of the initial per capita consumption, with the selection effect. Table 5 presents these results, for the baseline model and for the extended model. One of the first results to observe is that the disadvantage faced by ethnic minorities is consistent across the entire distribution, and not confined to the relatively poor, and persists after controlling for differences in key characteristics such as education. Some interesting differences also emerge for household demographics: illness seems to have a much bigger negative impact on the better-off households than on poorer households, possibly because the former are more likely to lose pay when ill, while poorer households adjust their labor inputs in own production activities. Having more adult members has a much greater positive effect for poorer households than for richer households, suggesting that additional adult labor can be used productively while having more children has a similar (but also positive) effect across the distribution. Given the uniformity of number of children in Vietnam, this latter result is perhaps not surprising.

Generally, we see that factors that drive improvements in consumption for the bottom third of the distribution are largely related to employment effects: the coefficients on the share of household members employed in the export sector along with the increase in commune level employment in the export sector are both positive and statistically significant, but none of the household level agricultural coefficients, not even the land rights coefficient, are statistically significant. While the changes in commune rice prices and rice productivity do have welfare enhancing effects for the bottom third, the employment effects appear to dominate. This finding that employment effects dominate at the lower end is also supported by the finding that having more adult labor has double the impact on household welfare among the poorest third than further up the distribution. In contrast, households in the upper third of the initial distribution, gained through a combination of improved productivity in rice production, having extended land use rights as well as employment effects.

The results from the three different approaches reported in this paper provide supporting evidence for the positive effect of the trade-related variables on household welfare in Vietnam during the 1990s. Our results are consistent with the Winters framework and remain robust to alternative uses of poverty lines and estimation techniques. To that extent, this paper concludes a positive effect of trade liberalization on rural poverty reduction with subtle effects via employment and prices.

Finally, it should be noted that some subtle differences emerge between the three approaches. Concentration in agriculture (captured by the head being employed in agriculture, having fewer household workers employed in the export 


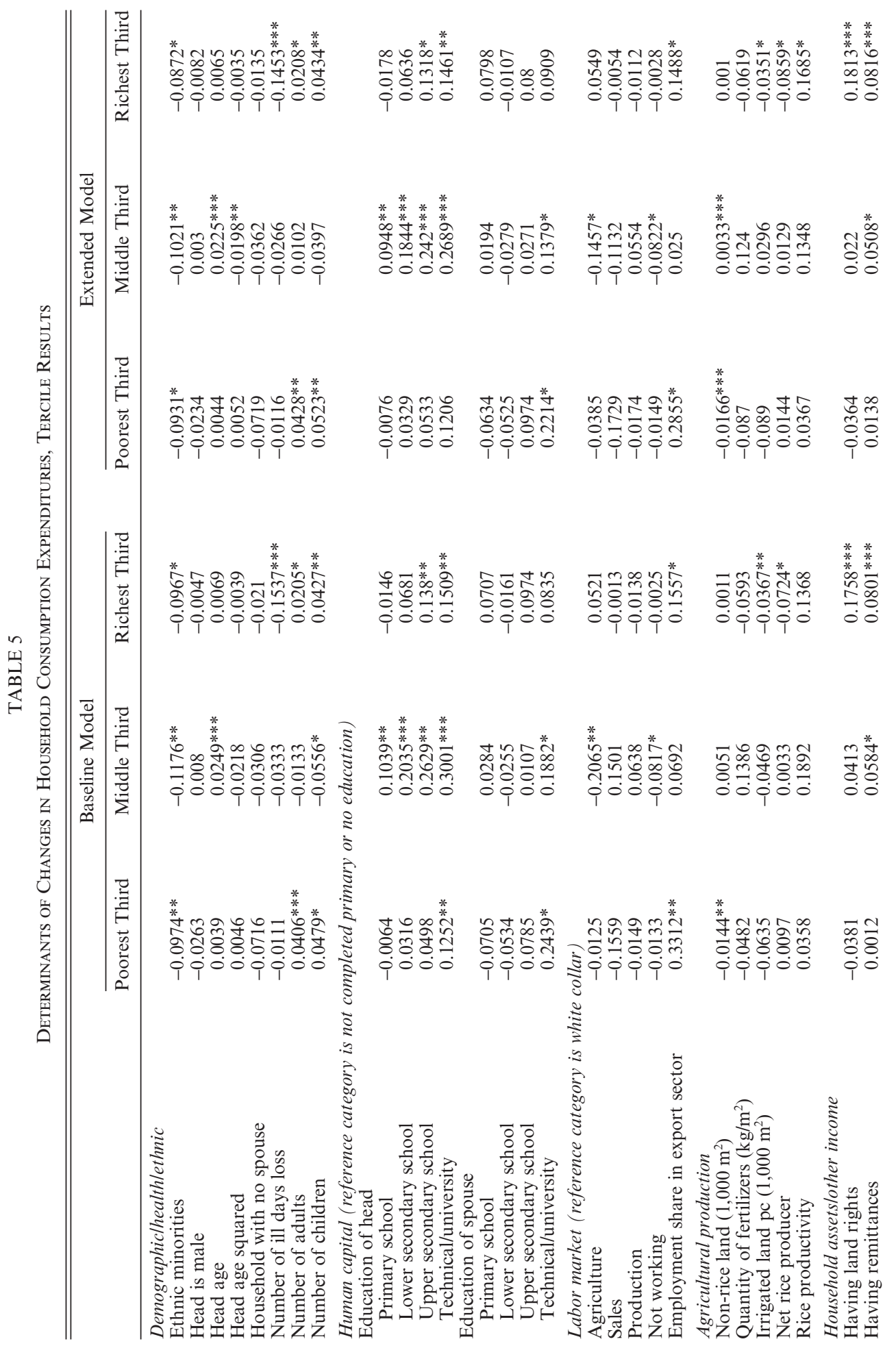




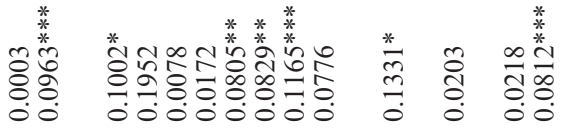
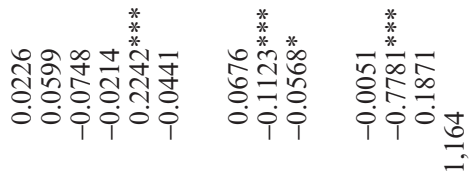

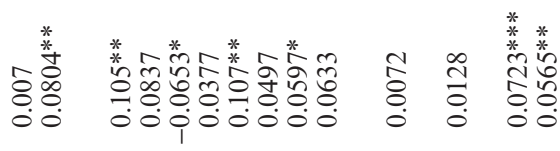

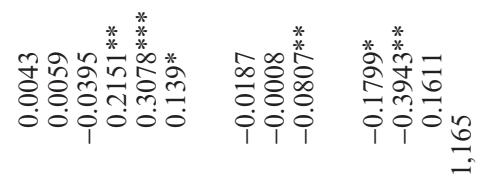

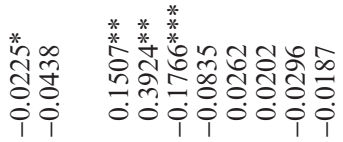
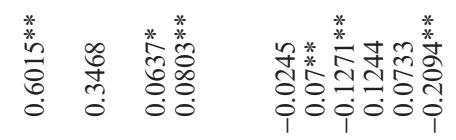

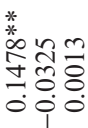

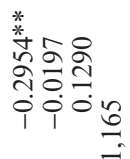

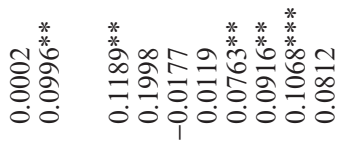

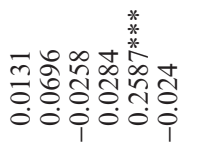
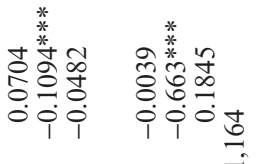

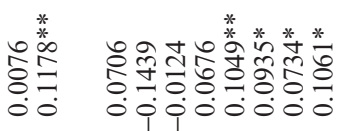

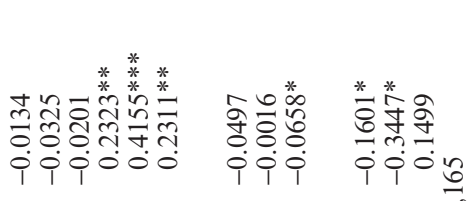
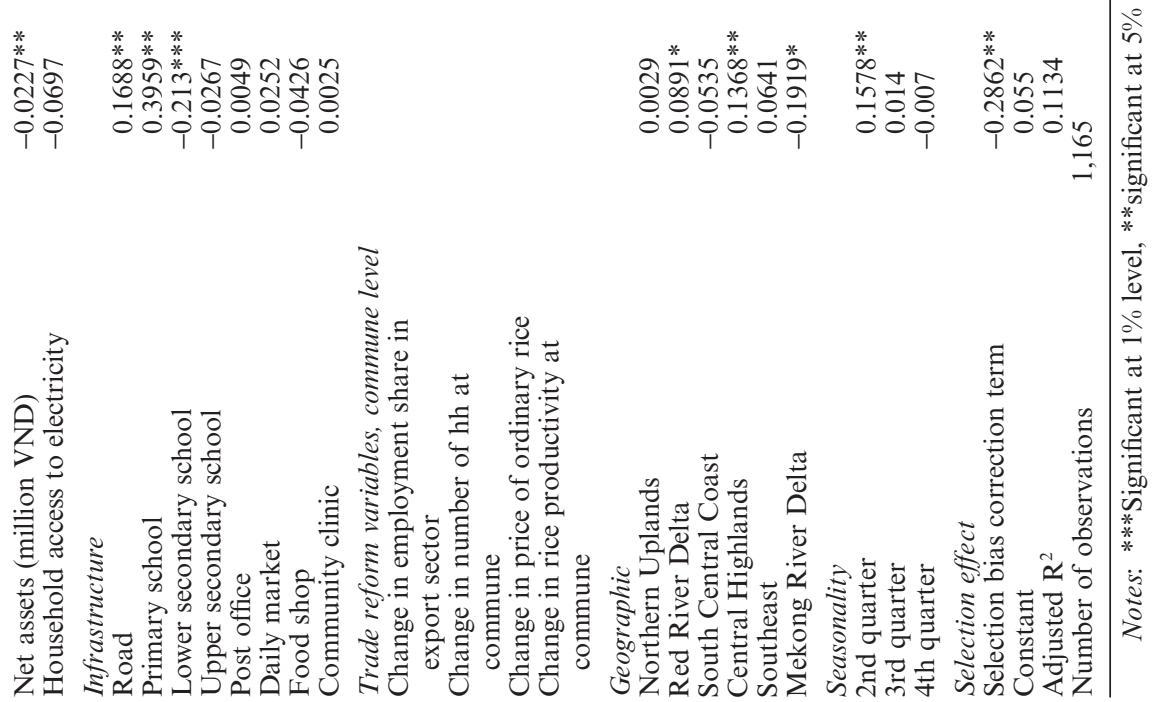
sectors, having more irrigated land per capita and higher usage of fertilizers) is found to have a negative effect on the mean of changes in expenditure over time, yet some of these factors (irrigation and fertilizer) are associated with higher probabilities of escaping from poverty and, for the top third of the distribution, more irrigated land is associated with increases in consumption. We believe that this illustrates the usefulness of going beyond regression at the mean and exploring other modeling strategies in order to capture the distributional effects created by growth. The poverty transition model, supported by the regressions for each third of the distribution, seems to provide more useful ways of modeling these differential impacts. Though our analysis is concentrated on the Vietnamese context, we believe that this suggestion is likely to be relevant in the context of other developing countries.

\section{Conclusions}

This paper analyzed poverty transitions in Vietnam during an intense period of economic reforms. We identified a set of variables that capture the transmission mechanisms associated with trade reforms implemented in Vietnam in the 1990s and estimated their impact on changes in per capita and adult equivalent consumption expenditure (at means and for different terciles) and on the probability of Vietnamese households becoming poor or moving out of poverty following the trade reforms. The analysis focused on the trade reform element of the doi moi on rural household welfare through its affects on prices (i.e. rice prices) and labor markets (i.e. employment in export sectors).

This paper makes a contribution to the empirical literature on the tradepoverty linkages. We show that the Winters (2002) framework linking trade liberalization and poverty is plausible and adds considerably to our understanding of the poverty impact of trade reform in the Vietnamese context. The results were generally consistent across different model specifications. We found that the tradeinduced employment effects were in general positive and had important welfareenhancing effects for the initially poor and for those in the bottom third of the initial consumption distribution, particularly via employment opportunities outside of agriculture in the emerging export sectors.

Although these results were robust to the use of both continuous and discrete variable models, we showed that the direct analysis of poverty outcomes and analysis of changes for different parts of the distribution, allowed more insightful conclusions than the analysis of changes in consumption expenditures at the mean. This is because the economic and social changes that have taken place in Vietnam during the 1990s have had both mean-enhancing and distributional expenditure effects, resulting in a variation of returns to trade-related variables along the consumption expenditure distribution, and between poor and non-poor households. This has important policy implications as poverty reduction strategies and safety net programs that often accompany trade liberalization policies rely on the ability of being able to identify those groups of households that are persistently poor and therefore particularly vulnerable to economic shocks.

Our research does however have at least two important limitations. Firstly, we remain cautious about how well the issue of endogeneity has been resolved, and 
in particular whether the community-level variables capture trade reforms or broader processes of transformation underway in Vietnam during the 1990s. Secondly, the paper does not address issues of sequencing of trade reforms nor complementarities between trade reforms and other policy reforms. The former would require, we believe, much more frequent waves of data, as well as an identifiable sequence of events to track, while the latter involves exploring counterfactuals. It is possible, for example, that the effects of the trade reforms would have been very different had agriculture not been decollectivized in the 1980s or land use rights formalized in the 1990s. While we find that households that had land use rights in 1992-93 did benefit more on average during the 1990s, our results suggest that the benefits accrued mainly to those in the top third of the distribution, while those further down the distribution gained much more from seeking employment in export sectors. How much of this last was due to the demand for labor in the export-sector or to an increased supply of labor freed from agriculture because of rising rice productivity and prices, and the role of decollectivization of agriculture in this process, must be the subject of further research.

\section{APPENDIX}

TABLE A1

Poverty Transition Matrix for Rural Vietnam, 1992-93 AND 1997-98

\begin{tabular}{|c|c|c|c|c|c|c|}
\hline \multirow[b]{2}{*}{ Category } & \multicolumn{2}{|c|}{$\%$ of Rural Panel } & \multirow{2}{*}{$\begin{array}{c}\text { Always } \\
\text { Poor }(\%)\end{array}$} & \multirow{2}{*}{$\begin{array}{c}\text { Non-poor } \\
\text { 1992-93 } \\
\text { Poor } \\
\text { 1997-98 }(\%)\end{array}$} & \multirow{2}{*}{$\begin{array}{c}\text { Poor 1992-93 } \\
\text { Non-poor } \\
1997-98(\%)\end{array}$} & \multirow{2}{*}{$\begin{array}{c}\text { Never } \\
\text { Poor }(\%)\end{array}$} \\
\hline & $1992-93$ & $1997-98$ & & & & \\
\hline $\begin{array}{l}\text { Rural Vietnam } \\
\text { Region }\end{array}$ & & & 33.9 & 5.4 & 29.7 & 31.1 \\
\hline Northern Uplands & 16.5 & 16.5 & 54.8 & 4.8 & 25.6 & 14.7 \\
\hline Red River Delta & 25.0 & 25.0 & 29.1 & 4.0 & 39.0 & 27.6 \\
\hline North Central & 15.7 & 15.7 & 41.1 & 4.6 & 33.3 & 21.1 \\
\hline Central Coast & 10.7 & 10.7 & 30.0 & 4.8 & 25.1 & 40.1 \\
\hline Central Highlands & 3.3 & 3.3 & 41.7 & 2.6 & 25.2 & 30.4 \\
\hline South East & 8.5 & 8.5 & 10.8 & 3.0 & 33.1 & 53.0 \\
\hline Mekong River Delta & 20.2 & 20.2 & 27.2 & 9.8 & 20.4 & 42.7 \\
\hline \multicolumn{7}{|l|}{ Ethnic group } \\
\hline Kinh & 84.8 & 84.6 & 28.0 & 5.4 & 31.9 & 34.8 \\
\hline Chinese & 0.4 & 0.3 & 28.0 & 0.0 & 8.0 & 64.0 \\
\hline Others & 14.9 & 15.1 & 67.7 & 5.3 & 17.6 & 9.5 \\
\hline \multicolumn{7}{|l|}{ Gender of head } \\
\hline Male & 78.0 & 76.6 & 28.3 & 6.2 & 28.5 & 36.9 \\
\hline Female & 22.0 & 23.4 & 35.5 & 5.1 & 30.0 & 29.4 \\
\hline \multicolumn{7}{|l|}{ Head age group } \\
\hline Under 30 & 14.6 & 5.9 & 46.2 & 8.1 & 28.3 & 17.5 \\
\hline 30 to 60 & 66.6 & 73.1 & 34.3 & 4.6 & 30.6 & 30.5 \\
\hline Above 60 & 18.9 & 21.0 & 26.0 & 6.7 & 27.3 & 40.0 \\
\hline \multicolumn{7}{|l|}{ Household size } \\
\hline Small ( $\leq 3$ members $)$ & 22.7 & 22.4 & 22.3 & 6.7 & 30.1 & 40.9 \\
\hline Medium (3-6 members) & 40.4 & 45.2 & 31.5 & 5.1 & 31.8 & 31.6 \\
\hline Large ( $\geq 6$ members) & 36.9 & 32.4 & 44.3 & 4.8 & 26.8 & 24.0 \\
\hline
\end{tabular}


TABLE A1 (continued)

\begin{tabular}{|c|c|c|c|c|c|c|}
\hline \multirow[b]{2}{*}{ Category } & \multicolumn{2}{|c|}{$\%$ of Rural Panel } & \multirow{2}{*}{$\begin{array}{c}\text { Always } \\
\text { Poor }(\%)\end{array}$} & \multirow{2}{*}{$\begin{array}{c}\text { Non-poor } \\
\text { 1992-93 } \\
\text { Poor } \\
\text { 1997-98 }(\%)\end{array}$} & \multirow{2}{*}{$\begin{array}{c}\text { Poor 1992-93 } \\
\text { Non-poor } \\
1997-98(\%)\end{array}$} & \multirow{2}{*}{$\begin{array}{c}\text { Never } \\
\text { Poor }(\%)\end{array}$} \\
\hline & $1992-93$ & $1997-98$ & & & & \\
\hline \multicolumn{7}{|l|}{ Head occupation } \\
\hline White collar & 3.4 & 4.3 & 11.2 & 2.6 & 27.1 & 59.1 \\
\hline Sales and services & 4.3 & 5.4 & 15.0 & 5.6 & 26.0 & 53.4 \\
\hline Agriculture & 75.2 & 71.8 & 37.5 & 5.5 & 30.1 & 27.0 \\
\hline Production & 7.8 & 8.2 & 27.9 & 4.5 & 33.6 & 34.1 \\
\hline Unemployed & 9.3 & 10.2 & 30.3 & 6.0 & 26.5 & 37.2 \\
\hline \multicolumn{7}{|l|}{ Head education } \\
\hline None & 39.3 & 10.9 & 41.4 & 5.7 & 24.0 & 28.9 \\
\hline Primary & 24.5 & 37.7 & 33.2 & 6.5 & 28.8 & 31.5 \\
\hline Lower secondary & 24.1 & 35.9 & 33.3 & 4.8 & 35.4 & 26.6 \\
\hline Upper secondary & 4.0 & 9.6 & 25.7 & 3.4 & 28.4 & 42.5 \\
\hline $\begin{array}{l}\text { Technical and } \\
\text { university }\end{array}$ & 8.1 & 5.9 & 20.4 & 3.3 & 30.8 & 45.5 \\
\hline
\end{tabular}

Source: Own calculations from the Vietnam Living Standards Survey 1992-93 and 1997-97.

TABLE A2

The 2SLS Approach-Diagnostic Tests for Instrument Relevance And Validity

\begin{tabular}{|c|c|c|}
\hline & $\Delta$ of Export Employment Share & $\Delta$ of Rice Productivity \\
\hline $\begin{array}{l}\text { Using the IV set } I^{\text {a }} \\
\text { F-test statistic } \sim \mathrm{F}(9,3437) \\
\text { Sargan test statistic } \sim \chi_{8}^{2} \\
\text { Hausman test statistic (t-test) }\end{array}$ & $\begin{array}{r}0.83 \\
23.77 \\
1.69\end{array}$ & $\begin{array}{r}3.38 \\
23.43 \\
-1.06\end{array}$ \\
\hline $\begin{array}{l}\text { Using the IV set } 2^{\mathrm{b}} \\
\text { F-test statistic } \sim \mathrm{F}(18,3428) \\
\text { Sargan test statistic } \sim \chi_{17}^{2} \\
\text { Hausman test statistic (t-test) }\end{array}$ & $\begin{array}{r}2.07 \\
228.46 \\
2.18\end{array}$ & $\begin{array}{r}5.03 \\
229.16 \\
1.07\end{array}$ \\
\hline $\begin{array}{l}\text { Using the IV set } 3^{\mathrm{c}} \\
\text { F-test statistic } \sim \mathrm{F}(9,3162) \\
\text { Sargan test statistic } \sim \chi_{8}^{2} \\
\text { Hausman test statistic (t-test) }\end{array}$ & $\begin{array}{r}6.27 \\
85.11 \\
0.98\end{array}$ & $\begin{array}{l}18.01 \\
83.39 \\
-4.70\end{array}$ \\
\hline $\begin{array}{l}\text { Using the IV set } 4^{\mathrm{d}} \\
\text { F-test statistic } \sim \mathrm{F}(20,3151) \\
\text { Sargan test statistic } \sim \chi_{19}^{2} \\
\text { Hausman test statistic }(\mathrm{t} \text {-test })\end{array}$ & $\begin{array}{r}8.50 \\
151.96 \\
-1.36\end{array}$ & $\begin{array}{r}41.02 \\
149.55 \\
-3.65\end{array}$ \\
\hline $\begin{array}{l}\text { Using the IV set } 1+3^{\mathrm{e}} \\
\text { F-test statistic } \sim \mathrm{F}(18,3153) \\
\text { Sargan test statistic } \sim \chi_{17}^{2} \\
\text { Hausman test statistic (t-test) }\end{array}$ & $\begin{array}{r}3.59 \\
106.83 \\
1.23\end{array}$ & $\begin{array}{r}11.21 \\
105.10 \\
-4.68\end{array}$ \\
\hline $\begin{array}{l}\text { Using the IV set } 1+4^{\mathrm{e}} \\
\text { F-test statistic } \sim \mathrm{F}(29,3142) \\
\text { Sargan test statistic } \sim \chi_{28}^{2} \\
\text { Hausman test statistic (t-test) }\end{array}$ & $\begin{array}{r}6.64 \\
172.64 \\
-1.22\end{array}$ & $\begin{array}{r}29.71 \\
170.23 \\
-3.70\end{array}$ \\
\hline $\begin{array}{l}\text { Using the IV set } 2+3^{\mathrm{e}} \\
\text { F-test statistic } \sim \mathrm{F}(27,3144) \\
\text { Sargan test statistic } \sim \chi_{26}^{2} \\
\text { Hausman test statistic (t-test) }\end{array}$ & $\begin{array}{r}3.46 \\
325.30 \\
2.30\end{array}$ & $\begin{array}{r}10.00 \\
324.61 \\
-3.00\end{array}$ \\
\hline
\end{tabular}


TABLE A2 (continued)

\begin{tabular}{lcr}
\hline \hline & $\Delta$ of Export Employment Share & $\Delta$ of Rice Productivity \\
\hline Using the IV set $2+4^{\mathrm{e}}$ & & \\
F-test statistic $\sim \mathrm{F}(38,3133)$ & 6.17 & 26.54 \\
Sargan test statistic $\sim \chi_{37}^{2}$ & 386.98 & 384.91 \\
Hausman test statistic (t-test) & -0.93 & -2.98
\end{tabular}

Notes:

${ }^{\text {a }}$ Set 1 is the simplest set of instruments, which includes nine household-level variables at the initial period: (i) initial-period household structure ratios (in total number of adults, aged 19-60 for men, and 19-55 for women): share of children aged 0-2; share of children aged 3-5; share of children aged 6-14; share of children aged 15-18; share of dependants (men aged 60+; women aged 55+); share of female adults (women aged 19-55); (ii) share of household members with educational levels from upper secondary and higher; (iii) share of household members working in agriculture as primary occupations; and (iv) total fertilizer used over the past 12 months (in $\mathrm{kg}$ ).

bet 2 is defined by adding the changes in those of Set 1 ("changes" are computed as the 1998 values minus 1992 values).

${ }^{\mathrm{c}}$ Set 3 consists of the commune-level variables at the initial period, such as average share of export sector employment; number of households; average rice productivity; average fertilizer quantity used; average irrigated land area; average non-rice land; price of paddy rice and ordinary rice; having supports in terms of infrastructure program, job creation support, and agricultural extension centers.

${ }^{\mathrm{d}}$ Set 4 is defined by adding to Set 3 the changes in those included in Set 3.

${ }^{\mathrm{e}}$ Set $1+3$ is formed by adding Set 3 to Set $1 ;$ Set $1+4$ is formed by adding Set 4 to Set $1 ;$ Set $2+3$ is formed by adding Set 3 to Set 2; and Set $2+4$ is formed by adding Set 3 to Set.

\section{REFERENCES}

Appleton, S., "The Rich Are Just Like Us, Only Richer: Poverty Functions or Consumption Functions?" Journal of African Economies, 10(4), 433-69, 2002.

Athukorala, P., Trade Policy Reforms, Export Strategies, and the Incentive Structure, background paper to the World Bank study "Vietnam's Exports: Policies and Prospects," World Bank Vietnam Office, Hanoi, 2002.

Auffret, P., Trade Reform in Vietnam: Opportunities with Emerging Challenges, Policy Research Working Paper No. 3076, Development Research Group, World Bank, Washington DC, 2003.

Bane, M. J. and D. T. Ellwood, "Slipping Into and Out of Poverty: The Dynamics of Spells," Journal of Human Resources, 21, 1-23, 1986.

Barro, R. J., "Economic Growth in a Cross Section of Countries," Quarterly Journal of Economics, 106, 407-43, 1991.

Baulch, B., K. Chuyen, D. Haughton, and J. Haughton, "Ethnic Minority Development in Vietnam: A Socioeconomic Perspective," in P. Glewwe, N. Agrawal, and D. Dollar (eds), Economic Growth, Poverty, and Household Welfare in Vietnam, World Bank Regional and Sectoral Studies, World Bank, Washington DC, 2004.

Benjamin, D. and L. Brandt, Agriculture and Income Distribution in Rural Vietnam under Economic Reforms: A Tale of Two Regions, William Davidson Working Paper No. 519, The William Davidson Institute, University of Michigan, 2002.

Dang, N. A. and K. S. Le, "Rural-Urban Labor Migration in Vietnam: New Insights from the 1999 Population Census," Vietnam's Socio-Economic Development, 30, 69-80, 2002.

Deaton, A., The Analysis of Household Surveys: A Microeconomic Approach to Development Policy, Johns Hopkins University Press, for the World Bank, Baltimore, 1997.

- Measuring Poverty in a Growing World (or Measuring Growth in a Poor World, NBER Working Paper No. 9822, National Bureau of Economic Research, 2003.

Dercon, S., "Growth and Shocks: Evidence from Rural Ethiopia," Journal of Development Economics, 74, 309-29, 2004.

Edwards, S., "Openness, Productivity and Growth: What Do We Really Know?" Economic Journal, 108, 383-98, 1998.

Gallup, J. L., "The Wage Labor Market and Inequality in Vietnam in the 1990s," in P. Glewwe, N. Agrawal, and D. Dollar (eds), Economic Growth, Poverty and Household Welfare in Vietnam, The World Bank, Washington DC, 2004.

Glewwe, P., M. Gragnolati, and H. Zaman, "Who Gained from Vietnam's Boom in the 1990s?" Economic Development and Cultural Change, 50(4), 773-92, 2002. 
Goldberg, P. K. and N. Pavcnik, Trade, Inequality and Poverty: What Do We Know? Evidence from Recent Trade Liberalization Episodes in Developing Countries, National Bureau of Economic Research Working Paper 10593, Cambridge, MA, 2004.

Greene, W. H., "Sample Selection Bias as a Specification Error: A Comment," Econometrica, 49(3), 795-98, 1981.

- Econometric Analysis, 4th edition, Prentice-Hall, Englewood Cliffs, NJ, 2000.

Haughton, D., J. Haughton, and N. Phong, Living Standards During and Economic Boom: The Case of Vietnam, UNDP and General Statistical Office, Hanoi, 2001.

Heckman, J., "Sample Selection Bias as a Specification Error," Econometrica, 47(1), 153-61, 1979.

Jenkins, R., Globalization and Employment in Vietnam, Discussion Paper No. 11, DFID research program on "Globalization and Poverty," 2003.

Justino, P. and J. Litchfield, Poverty Dynamics In Rural Vietnam: Winners and Losers During Reform, PRUS Working Paper No. 10, Department of Economics, University of Sussex, Brighton, UK, 2003.

Koenker, R., Quantile Regression, Cambridge University Press, Cambridge, 2005.

Lanjouw, J. O. and Peter Lanjouw, "How to Compare Apples and Oranges: Poverty Measurement based on Different Definitions of Consumption," Review of Income and Wealth, 47(1), 25-42, 2001.

Lipton, M. and M. Ravallion, "Poverty and Policy," in J. Behrman and T. N. Srinivasen (eds), Handbook of Development Economics, vol. 3B, Elsevier, Amsterdam, 1995.

Litchfield, J. and P. Justino, "Welfare in Vietnam During the 1990s: Poverty, Inequality and Poverty Dynamics," Journal of the Asian Pacific Economy, 9(2), 145-69, 2004.

Main, B. G. M. and B. M. Reilly, "The Employer Size-Wage Gap: Evidence for Britain," Economica, 60(238), 125-42, 1993.

Mankiw, N. G., D. Romer, and D. N. Weil, "A Contribution to the Empirics of Economic Growth," Quarterly Journal of Economics, 107, 409-37, 1992.

McCulloch, N., A. Winters, and X. Cirera, Trade Liberalisation and Poverty: A Handbook, CEPR, London, 2001.

Nielsen, C. P., Vietnam in the International Rice Market: A Review and Evaluation of Domestic and Foreign Rice Policies, Fødevareøkonomisk Institut, Rapport 132, 2002.

Niimi, Y., P. Vasudeva-Dutta, and L. A. Winters, "Trade Liberalisation and Poverty Dynamics in Vietnam," PRUS Working Paper No. 17, Department of Economics, University of Sussex, Brighton, UK, 2002.

PTF, Localizing MDGs for Poverty Reduction in Vietnam: Enhancing Access to Basic Infrastructure, report by Poverty Task Force, World Bank Vietnam Office, Hanoi, 2002.

Ravallion, M., The Debate on Globalization, Poverty and Inequality: Why Measurement Matters, Policy Research Working Paper 3038, World Bank, 2003.

Rodriguez, F. and D. Rodrik, Trade Policy and Economic Growth: A Sceptic's Guide to the CrossNational Evidence, CEPR Discussion Papers, Series No. 2413, 1999.

Sachs, J. and A. Warner, "Economic Reform and the Process of Global Integration," Brookings Papers on Economic Activity, 1, 1-95, 1995.

Small, K. A. and C. Hsiao, "Multinomial Logit Specification Tests," International Economic Review, 26(3), 619-27, 1985.

Stewart, M. B., "On Least-Squares Estimates When the Dependent Variable is Grouped," Review of Economic Studies, 50, 141-9, 1983.

Swinkels, R. and C. Turk, "Explaining Ethnic Minority Poverty in Vietnam: A Summary of Recent Trends and Current Challenges," background paper for CIEM/MPI meeting on Ethnic Minority Poverty, Sept 2006, Hanoi, 2006.

Van de Walle, D. and D. Cratty, Is the Emerging Non-Farm Market Economy the Route Out of Poverty in Vietnam?, Policy Research Working Paper No. 2950, Development Research Group, World Bank, Washington DC, 2003.

VLSS, Vietnam's Living Standards Survey 1997-98: Basic Information, Poverty and Human Resources Division, World Bank, 2001.

Wills, H., "A Note on Specification Tests for the Multinomial Logit Model," Journal of Econometrics, 34, 263-74, 1987.

Winters, L. A., "Trade, Trade Policy and Poverty: What Are the Links?" World Economy, 25, 1339-67, 2002.

World Bank, Vietnam Development Report 2000: Attacking Poverty, Joint Report of the Government, Donor and NGO Working Group, Consultative Group Meeting for Vietnam, December 14-15, 2000 . 